\title{
Factors Influencing the Improvement of Students' Writing Skill Through Peer Editing Technique
}

\author{
Yola Merina ${ }^{1}$, Rani Autila ${ }^{2}$, Yelliza ${ }^{3}$ \\ 1,2,3Pendidikan Bahasa Inggris, STKIP PGRI Sumatera Barat, Padang \\ e-mail: yolam3@gmail.com,rraniautila@yahoo.com,yellizajr@gmsil.com
}

\begin{abstract}
This research investigated the students' writing skill on recount text at session 2016 A English Department of STKIP West Sumatera. Some of them had difficulties in organization, content, grammar, mechanic, and vocabulary. Then, they really need lecturers' correction in every step of their writing process. Therefore, the researcher applied peer editing technique as the focus of research to solve this problem. The purposes were to find whether peer editing technique can improve students' writing skill on Recount Text and some factors influence the improvement. The methodology of research is a classroom action research (CAR). Researcher used writing test and questionnaire as the instruments. The finding of the research showed that the students' writing skill of recount text improves through Peer Editing technique and there are four factors influenced the improvement.
\end{abstract}

Keywords: peer editing technique, recount text

\section{Introduction}

Teaching English as a foreign language has many challenges, especially in Indonesia which has many traditional languages. It can be seen from some lecturers' problems in their teaching learning process. Especially in teaching writing, the students are really need lecturers' correction during every step of their writing process. Unfortunately, the lecturer cannot give full attention for all students because of time limitation and class size which can be about forty students. Thus, their grade of writing skill was not satisfied enough.

Based on those facts, the lecturers try to use the appropriate teaching technique that can help lecturer to solve the problems. Peer editing technique seems to be one of the effective teaching techniques to improve students' writing skill of Recount Text. In peer editing technique, the students are providing feedback on their friends' writing that related to the organization, content, vocabulary, grammar, and mechanic in order to make their friends' writing clearer. It is the process of sharing each other's writing between students as a peer to see whether their writing has successful delivered intended meaning and to get the point of view from peer as the reader in order to improve their writing by his peer feedback. It is a two-way street which students learn to be a good writer and reader.

By Peer editing technique, the students can be more independent inside and outside the classroom in order to improve their writing skill. Thus, they can develop their writing skill as much as possible. During independent writing, the students produce their own writing text based on lecturer's explanation of text characteristics related to genre. Then, the students' first draft will be edited by their peer in peer editing process. It is the point of students' independence. Consequently, the lecturer can be functioned as a guide not as a corrector. Therefore, the researcher carried out a research to find out how peer editing technique could improve students' writing skill of Recount Text and some factors influence the improvement.

Writing skill is important for students in order to meet with the academic demand and workplace. It is a predictor of students' academic success and a major requirement for participation in civic life. If students want to write something, they must transfer idea into language, make the language used can be understandable, transform their ideas properly and naturally in a good and interesting writing. Thus, to do those they need to have a good writing skill.

In fact, based on the observation, interview, and result of students' writing, the researcher found that a number of students at session 2016 A English Department of STKIP PGRI West Sumatera do not have a good ability of writing Recount Text. It can be seen from 
their low grade of writing skill. The researcher found that the mean score of students' writing skill on Recount Text only 62 from the maximum score 100. It was counted by using analytical scale for Recount Text modified from Brown. A part of students do not understand the organization of the text and how to use the appropriate tenses. It happens because they do not have enough basic skill of writing principles and less allocation time for writing. As the consequence, students' writing skill does not meet expectations for quality. Those students' problems of writing make them difficult to produce a good writing project. However, students actually can do a better writing if they are taught by an appropriate teaching writing technique. Some lecturers usually tend to use product oriented approach rather that process oriented approach. For the outstanding class, the students are active and reactive. They can be more motivated if the lecturer gives them an occasion to be more critical, expressive, and reflective through process oriented approach.

Thus, it is important for lecturer to use peer editing technique in the process of writing at session 2016 A English Department of STKIP PGRI West Sumatera to help students be more active, reactive, creative, responsible, autonomous, critical, expressive and reflective writer. The technique was used because in peer editing technique students have to edit their friends' writing in detail. It helps students to do reflection on their own and become more careful on their writing because it would be read by their friends and got more than one point of view from the readers. The researcher used this technique for session $2016 \mathrm{~A}$ which had qualified students to be taught by using peer editing technique to improve the teaching learning process in writing skill.

The knowledge around writing skill has been developed by some experts. However, each of them has a different point of view in defining it. The term of writing skill is really important in order to limit how far the writing ability can be categorized as a skill. Hedge (2007) defines writing skill as an ability in using some strategies to manage the writing process. In this definition, Hedge states that the writing strategies are number of activities such as planning goals, generating ideas, organizing information, selecting appropriate word, making a draft, reviewing, editing and revising it. Furthermore, Amato and Patricia (2003) define writing skill as an ability to use some strategies for dealing with the problems in writing process. In this definition, Amato and Patricia have an opinion that the strategies include brainstorming for topic, collecting information for writing the draft, clustering the information, writing the rough draft, consulting with peer or lecturer, and revising it. Based on those definitions, the researcher concludes that writing skill is an ability of writer to write with fluency, as natural as possible with the accuracy of grammar, the coherent and authentic ideas, clear purpose of writing and reader in mind, and using some strategies for dealing with the problems in writing process in order to get the best writing product.

Recount text is a text that tells about events occurred in the past. It is one of the texts that helps students to develop their experience into writing. According to Wardiman (2005:115), recount text is used to tell past events, such as holiday experience, accidents, and activity report. It seems similar with anecdote, but anecdote is used to tell events that is funny and entertaining. Meanwhile, Knapp and Megan (2005:223) state that Recount Text is the simplest text type which tells sequence of events with generic structure such as orientation, events and reorientation. Indeed, it is impossible to tell a story unless we show characters set up in a particular time and place. Next, Corbett and Julia (2011:49) state that Recount Text is one of the easier non-fiction types which focuses on telling what happened. The differences with Narrative Text is that narrative is imaginative and made up, when Recount Text should be retelling series of events that have actually happened: in the first person it is a personal recount, and in the third person it is recounting events that have happened to others. In conclusion, Recount Text is a text that tells experience or past event to the reader. Recount text can be in the form of dialogues and written text. This text helps students to increase their writing achievement by telling events in the past.

Marsh (2018) has found young writers in the online space Fan Fiction.net sharing work with large audiences of peers who provide feedback in the form of "reviews". These 
writers value reviews as important critical feedback. This research found peer feedback lacking, as it provides little guidance on improving text quality. Research finding shows the social connection and support students provide to each other back grounded in these studies, which focus rather on writing quality improvement as the benchmark for peer feedback's effectiveness.

Nahdi (2011) has done a research entitled 'Improving Students' Writing Ability by Using Peer Editing Technique at the Third Semester Students of English Study Program of STKIP Hamzanwadi Selong". It provides frameworks for pairs or small groups to help each other and critique final and graded written products. The research consists of three cycles. Each cycle consists of three meetings to write paragraph draft, to exchange ideas with pair, to do peer editing, to revise the draft, and to discuss the students' difficulties. The result of the study show that peer-editing technique can improve students' ability in writing an expository paragraph and improve classroom situation in writing class.

Furthermore, Baroroh (2011) conducted a research entitled "The Use of Mind Mapping and Peer-Editing Techniques to Improve Students' Writing Skill at the Tenth Grade Students of SMA Negeri I Karanganyar". It was conducted in two cycles. The researcher found that mind mapping and peer-editing technique improve the students' writing skill especially on the aspects of content, organization of ideas and language features. It is proved by the significant increase of the mean score of the post- test cycle 1 and post-test cycle 2. Second, those techniques cover on the planning stage and revising stage in the process of writing. As the result, there is no missing stage from pre-writing to postwriting.Third, students also actively involved in the teaching-learning process.

Then, Arini (2012) conducted a research entitled“Using Peer Editing Technique and Revising Technique in Process Approach to Improve the Students' Ability in Writing Argumentative Essay at Lambung Mangkurat University". The implementation of peer editing and revising techniques was started by reviewing the argumentative essay, conducting pre writing and drafting in groups. Then, the researcher gave modeling of peer-editing and revising techniques. She asked the students to conduct peer editing and revising techniques based on the rubrics given and asked them to prepare for group presentation. Then, they publish their work on the wall board. The result of the study shows that the use of peer editing and revising techniques can improve the students' writing ability in writing argumentative essay. The students' participation and response was also achieved.

Moreover, Fajriah (2012) has done a research entitled 'Improving Students' Writing Skill in Descriptive Text through Brainstorming and Peer Editing Techniques at Third Grade Students' of Sentolo Kulon Progo". It was conducted in two cycles. The result of the study shows that brainstorming and peer editing techniques can improve students' writing skill in descriptive text. It proved through the increasing of writing score at the end of the second cycles. Students also became more activated and motivated in the teaching learning process. From the number of related studies above, it shows that peer editing technique contributes good effect on the students' writing skill.

Lecturer should give some rules to do peer editing technique to make the editing process have a value for the writer. According to Oshima and Ann (2006) some advices for peer editor are:(a) help peer's writing be clearer; (b) do not cross out; (c) give positive comment first; (d) use a colored ink; (e) discuss your opinion. When students have understood some advices to do peer editing, it is important to explain some steps to do it. Balushy (2013)states that some steps for conducting peer editing technique: (a) choose the pair, it can be randomly; (b) provide worksheet; (c)peer editor circle the mistakes; (d) let students to consult with peer editor for clarification; (e) have writers to revise their paper. Further, Hadley (2001) states some steps for conducting peer editing technique by class are: (a) read a draft; (b) provide grammatical correction; (c) provide content and vocabulary correction; (d) look for organization; (e) offer general comments. Next, Rathvon (2008) states some steps for conducting peer editing technique: (a) lecturer explains the characteristics of the text; (b) lecturer demonstrates how to do peer editing; (c) students make a first draft; (d) peer editor read the text; (e) peer editor discusses his suggestion with the author; (f) students work independently to revise their own paper. Briefly, some points for conducting 
peer editing technique: (a) lecturer explains the characteristics of the text that will be written and shows the example, (b) lecturer demonstrates how to do peer editing by giving clear feedback on the error writing and she lets students to use dictionaries, grammar book and class notes while correcting the mistakes, (c) students have to make a first draft by outlining and writing to be edited, (d) students exchange the draft with their partner; it can be allocated randomly or by lecturer's decision, (e) students spot the mistakes on partner's draft and fill in peer editing worksheet provided by lecturer, then students provide feedback by reading, asking questions, giving comment and correcting, and then feedback given can be about strength and weaknesses that related to the organization, content, grammar, punctuation, spelling, and vocabulary, (f) students consult with their peer editor for clarification of the feedback to make the editing clearer, $(g)$ students revise their own paper independently as the final draft. The experience as peer editor helps them to do reflection on their own.

Since the researcher has a similar case with the previous researchers which is their students have problems in gathering, developing, and organizing ideas, vocabulary, punctuation, spelling, and grammar, thus, the researcher used peer editing technique and adapted some steps from previous research that appropriate with the students at session 2016 A English Department of STKIP PGRI West Sumatera. In short, this research aims to find out to what extent peer editing technique improves students' writing skill of Recount Text at session 2016 A English Department of STKIP PGRI West Sumatera and to find out some factors influence the improvement of students' writing skill on Recount Text through Peer Editing Technique.

\section{Method}

The instruments of this research is observation sheet, field note, and questionnaire for qualitative data. In having questionnaires, the researcher follows Creswell ideas (2012:220) where the scores of each response are $5=$ strongly agree, $4=$ agree, $3=$ undecided, $2=$ disagree, and 1 = strongly disagree. Further, according to Oxford (1990) the value scale for questionnaire are 1.00-1.50= strongly disagree (SD), $1.51-2.50=$ disagree (D), $2.51-3.50=$ undecided $(\mathrm{U}), 3.51-4.50=$ agree $(\mathrm{A}), 4.51-5.00=$ strongly agree $(\mathrm{SA})$. At the end of the cycle, the researcher conducted a writing test. To ensure the validity of the test, the researcher conducted it based on the lesson plan of writing class. Then, to judge the reliability of the test, the researcher asked her collaborator to test her students' writing skill by using the same criteria. Furthermore, the result of the test was analyzed by using analytical rubric suggested by Weigle (2002:116). The indicators were generic structure of Recount Text (orientation, events, and reorientation), content, grammar (language features of Recount Text), mechanics, and vocabulary. Then, to get the average grade of students' writing skill of Recount Text in each cycle, the researcher found the mean score. Based on the data gathered, the researcher knew the achievement of the students' writing.The formula to get the mean score suggested by Gay and Airasian (2000:454) as follow:

Where:

$$
x=\frac{\sum x}{N}
$$

$$
\begin{array}{ll}
\sum_{\mathrm{X}} & =\text { the sum of all scores } \\
\mathrm{N} & =\text { the mean, or arithmetic average of scores } \\
& =\text { total number of participants }
\end{array}
$$

The action research has a cyclical process. Each cycle consisted of several steps. The model proposed by Kemmis and Robin (1998:14) was known as the action research spiral that consisted of four steps. They were planning, action, observation, and reflection. Based on this theory, the research was conducted in two cycles. The cycle consisted of six meetings. The meeting equaled two hours (2x50 minutes). The teaching steps for peer editing technique as follows: 


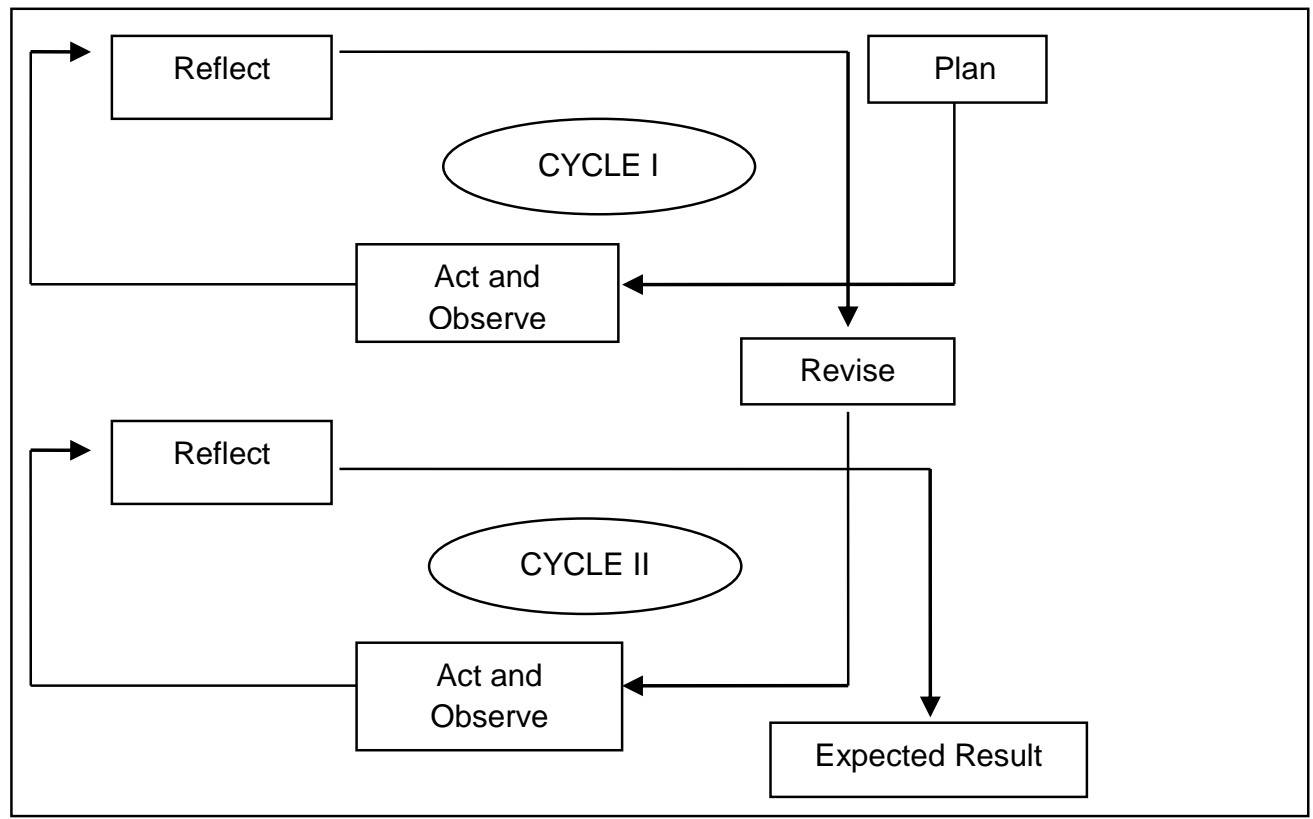

Chart 1. The Procedure of Classroom Action Research

(Kemmis and Robin, 1998:12)

In quantitative analysis, the students' score of writing test was taken as the data. First, the researcher collected the data from first cycle in order to generalize it easily. The writing test was analyzed by using writing rubric. The rubric was taken from analytical rubric by Weigle (2002:116). There were five aspects that was evaluated such as generic structure (orientation, events, and reorientation), content, grammar (language features), mechanic and vocabulary. The researcher with the help from two other English lecturers analyzed the data to get students' score. The researcher and those English lecturers categorized students' writing into the levels in each indicator that was described in the scoring rubric. It revealed the students' strength and weakness point in developing the Recount Text concerning with generic structure (orientation, events, and reorientation), content, grammar (language features), mechanic and vocabulary. Then, the researcher accounted the percentage of the students' score in each indicator. Further, the students' total score was gotten after calculating all percentage resulted from each indicator. To get the mean score of students' writing test, the researcher calculated all students' score and divided it with the number of students which twenty eight people. To get the mean score of each indicator, the researcher calculated all students' score per indicator and divided into number of students which was twenty eight. The mean was used to see the average score of writing skill in the cycle. It was displayed in a table to see the comparison of both mean score before treatment by peer editing technique and after treatment. The formula to find the mean score can be seen in the writing test instrument. In order to make the chart balance from one indicator to others, the researcher calculated students' mean score per indicator divided with maximum score per indicator times with 100.

\section{Results and Discussion}

The Extent to Which Peer Editing Technique Improve Students' Writing Skill on Recount Text

The researcher analyzed the quantitative data which involved the mean score of students' writing test on Recount Text before treatment and after treatment of Peer Editing technique in first cycle. The mean score was gotten from two collaborators who scored the test. It involved the indicators of writing skill such as organization (generic structure), content, grammar, mechanic and vocabulary. After analyzing the data, the researcher found that there was an improvement of the students' writing skill on Recount Text through the 
process of Peer Editing technique. The grade from two collaborators as the scorer can be seen below:

Table1. Mean Scores of Students' Writing Skill on Recount Text before Treatment, after Cycle I and Cycle II from Each Score

\begin{tabular}{|c|c|c|c|c|c|c|c|c|c|c|c|c|c|c|c|}
\hline \multirow{3}{*}{$\begin{array}{c}\text { Lectu } \\
\text { rers }\end{array}$} & \multicolumn{15}{|c|}{ Students' Mean Score } \\
\hline & \multicolumn{3}{|c|}{ Generic Structure } & \multicolumn{3}{|c|}{ Content } & \multicolumn{3}{|c|}{ Grammar } & \multicolumn{3}{|c|}{ Mechanic } & \multicolumn{3}{|c|}{ Vocabulary } \\
\hline & $\begin{array}{l}\text { Befor } \\
\text { e } \\
\text { Treat } \\
\text { ment }\end{array}$ & $\begin{array}{l}\text { Cy } \\
\text { cle } \\
\text { I }\end{array}$ & \begin{tabular}{|l|} 
Cy \\
cle \\
II
\end{tabular} & $\begin{array}{l}\text { Befor } \\
\text { e } \\
\text { Treat } \\
\text { ment }\end{array}$ & $\begin{array}{l}\text { Cy } \\
\text { cle } \\
\text { I }\end{array}$ & $\begin{array}{l}\text { Cy } \\
\text { cle } \\
\text { II }\end{array}$ & $\begin{array}{l}\text { Befor } \\
\text { e } \\
\text { Treat } \\
\text { ment }\end{array}$ & $\begin{array}{l}\text { Cy } \\
\text { cle } \\
\text { I }\end{array}$ & $\begin{array}{l}\text { Cy } \\
\text { cle } \\
\text { II }\end{array}$ & $\begin{array}{l}\text { Befor } \\
\mathrm{e} \\
\text { Treat } \\
\text { ment }\end{array}$ & $\begin{array}{l}\text { Cy } \\
\text { cle } \\
\text { I }\end{array}$ & $\begin{array}{l}\text { Cy } \\
\text { cle } \\
\text { II }\end{array}$ & $\begin{array}{l}\text { Befor } \\
\text { e } \\
\text { Treat } \\
\text { ment }\end{array}$ & $\begin{array}{l}\text { Cy } \\
\text { cle } \\
\text { I }\end{array}$ & $\begin{array}{l}\text { Cy } \\
\text { cle } \\
\text { II }\end{array}$ \\
\hline $\begin{array}{l}\text { Scor } \\
\text { er } 1\end{array}$ & 65.2 & 80.6 & 81.4 & 62.1 & 71.1 & 78 & 53.8 & 68.2 & 75 & 64.8 & 77.6 & 79.2 & 65.6 & 79.0 & 81.4 \\
\hline $\begin{array}{l}\text { Scor } \\
\text { er } 2 \\
\end{array}$ & 69.2 & 80.4 & 82.6 & 64.4 & 69.2 & 81.1 & 50.9 & 65.3 & 70.6 & 64.0 & 80.8 & 82.4 & 63.2 & 75.8 & 81.2 \\
\hline $\begin{array}{c}\text { Mean } \\
\text { Scor } \\
\mathrm{e} \\
\end{array}$ & 67.2 & 80.5 & 82 & 63.3 & 70.1 & 79.5 & 52.4 & 66.8 & 72.8 & 64.4 & 79.2 & 80.8 & 64.4 & 77.4 & 81.3 \\
\hline
\end{tabular}

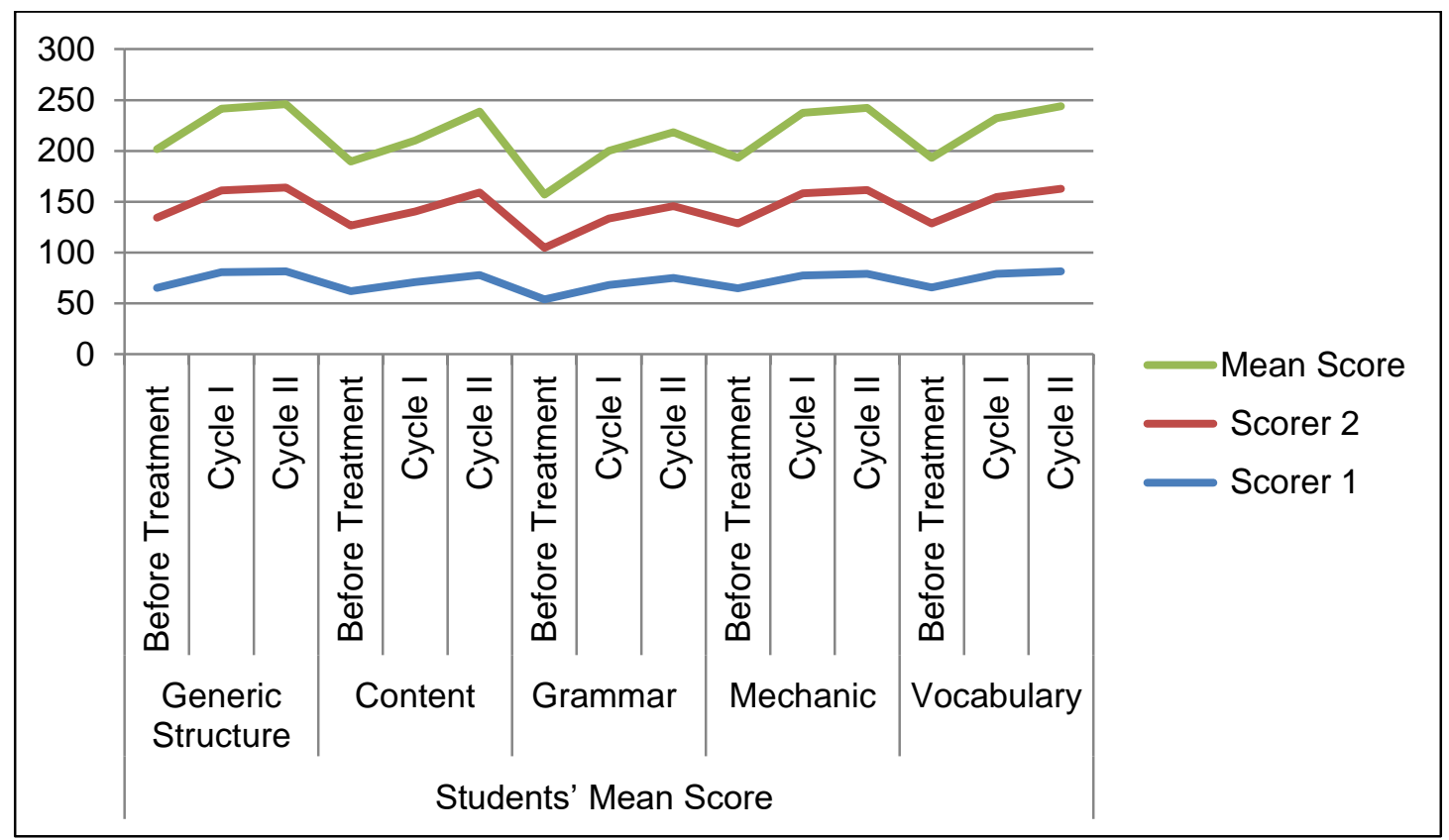

Figure 1. Mean Score of Students' Writing Skill on Recount Text before Treatment, after Cycle I and Cycle II from Each Scorer

Table2. Mean Scores of Students' Writing Skill on Recount Text before Treatment and after Cycle I from Two Scorers 


\begin{tabular}{clccc}
\hline & Indicators & Before Treatment & First Cycle Test & Improvement \\
\hline 1 & Generic structure & 67.2 & 80.5 & 13.3 \\
2 & Content & 63.3 & 70.1 & 6.9 \\
3 & Grammar & 52.3 & 66.7 & 14.4 \\
4 & Mechanic & 64.4 & 79.2 & 14.8 \\
5 & Vocabulary & 64.4 & 77.4 & 13.0 \\
\hline & Mean Score & 62.3 & 75 & 12.5 \\
\hline
\end{tabular}

Here is the following diagram of students' writing skill on Recount Text before treatment after cycle I

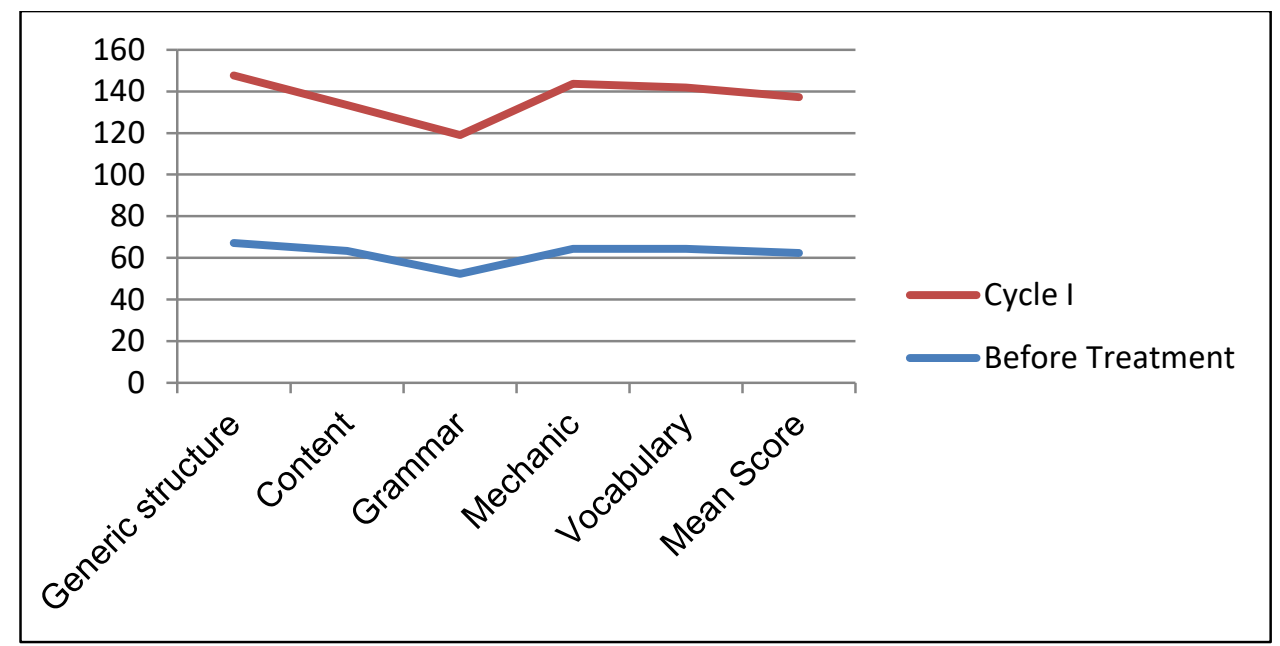

Figure 2. Mean Scores of Students' Writing Skill on Recount Text before Treatment and after Cycle I from Two Scorers

To see the improvement of students' writing skill on Recount Text before treatment and after cycle I, here is the pie chart.



Figure 3. Improvement of Students' Writing Skill on Recount Text before treatment and after Cycle I 
Table 3. Mean Scores of Students' Writing Skill on Recount Text from Cycle I to Cycle II from Two Scorers

\begin{tabular}{clccc}
\hline No & \multicolumn{1}{c}{ Indicators } & Cycle I & Cycle II & Improvement \\
\hline 1 & Generic structure & 80.5 & 82 & 2 \\
2 & Content & 70.2 & 79.5 & 9 \\
3 & Grammar & 66.8 & 72.8 & 6 \\
4 & Mechanic & 79.2 & 80.8 & 2 \\
5 & Vocabulary & 77.4 & 81.3 & 4 \\
\hline & Mean Score & 74.82 & 79.3 & 4 \\
\hline
\end{tabular}

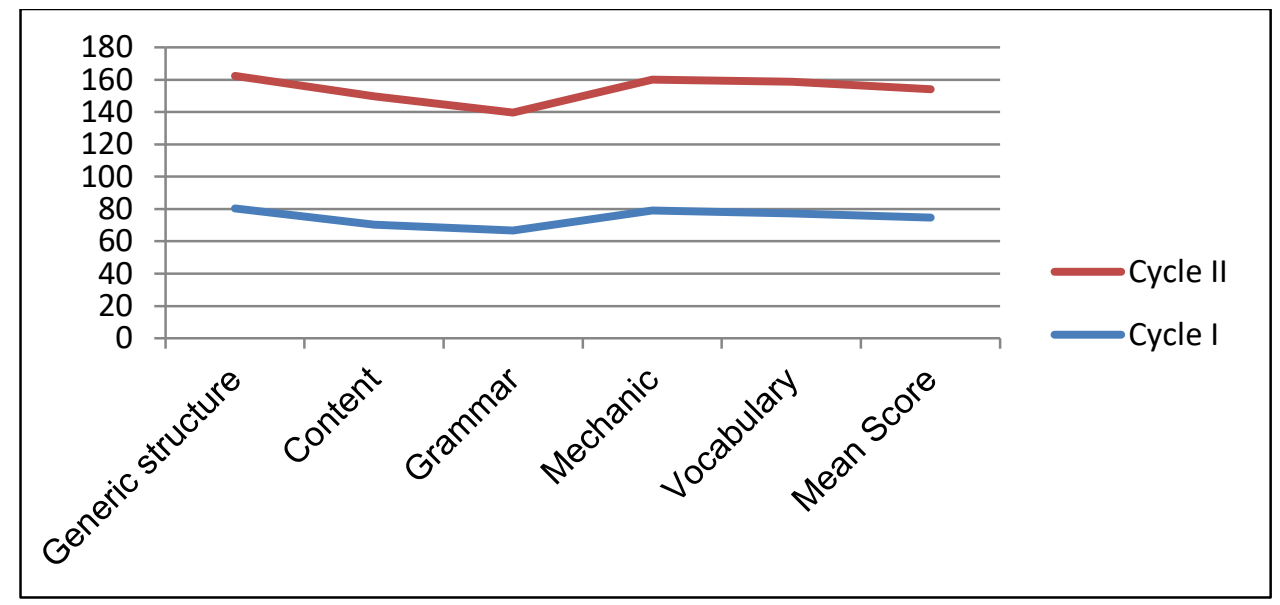

Figure 4. Mean Scores of Students' Writing Skill on Recount Text from Cycle I to Cycle II from Two Scorers

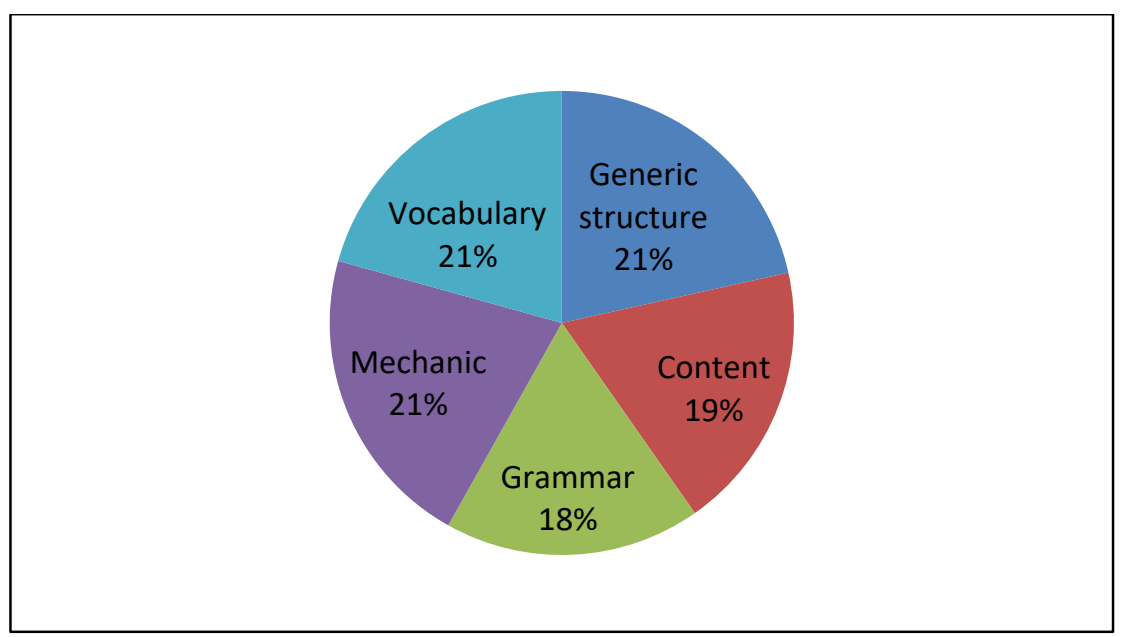

Figure 5. Improvement of Students' Writing Skill on Recount Text from Cycle I to Cycle II

The improvement of generic structure on students' writing skill of Recount Text from 67.2 to 80.5 to 82 was caused by peer editing done by the students. Each of them criticized their peer's writing. It helped them to do reflection on their own. Thus, they became more detailed to revise their writing because of some feedback given by their peer in peer editing worksheet. When their peers made three components of generic structure of Recount Text (summary of the event, background of the event and sources) became one paragraph, they criticized their peer and did reflection on their own wether they also made the same. 
The development of content of students' Recount Text from 63.3 to 70.2 to 79.5 was influenced by peer editing technique. When students read their peer's Recount Text, they gave some inputs if the information incomplete or inappropriate. Thus, the students as writer added some new information in revising process.

Then, the development of grammar from 52.3 to 66.8 to 72.8 also was influenced by peer editing technique. When the students as reader found some grammar mistakes on their peer' writing, they spotted the mistakes and wrote the right one to make the students as writer easier to revise the text. Then, the students as reader did reflection on their own weather they made the same grammar mistakes or not. Further, the students as writer did clarification if the feedback from their peer were wrong. In clarification process, students did discussion about the grammar mistakes. Thus, they shared knowledge each other. It helped them to understand more about the grammar or language features of Recount Text. Those processes also happened when students corrected mechanical and vocabulary so that there was improvement of mechanic from 64.4 to 79.2 to 80.8 and vocabulary from 64.4 to 77.4 to 81.3. Finally, the developments of students' mean score of Recount Text was from 62.3 to 75 to 79.3 .

The Factors Influenced the Improvement of Students' Writing Skill on Recount Text Through Peer Editing Technique at session 2016 A English Department of STKIP PGRI West Sumatera.

The researcher analyzed quantitative data based on the result of questionnaire. After analyzing the data, the researcher found several factors that improve students' writing skill on Recount Text through Peer Editing technique, those are (1) topic, (2) connecting reading and writing, (3) authentic and interactive activities, (4) learning process from planning to revising stage.

First, the interesting topic made students become more motivated to write, develop their ideas, and find more information to support their writing. According to Harmer (2007) students learn more successfully when they are interested on the topics that teacher provided. Then, Bolton (2013) adds giving learners chance to write about whatever they want is important. They were motivated to write if the topic was important to be written. Further, their background knowledge on the topic helped them to do prewriting easily. Moreover, the topic that was appropriate with the culture and students' ages also helped them to get the ideas flow. Then, the questionnaire result can be seen below.

Connecting reading and writing made students became easier to develop their ideas and get the model of writing independently. According to Brown (2001), students learn to write successfully and independently by carefully observing the text that has already been written. Reading before writing helped students to get more information to be written in the first draft. Thus, their first draft could be well developed. Further, reading partner's writing carefully before correcting helped students to edit and give appropriate comment. Moreover, reading partner's writing before revising their own helped students to do reflection. So that, they would not do the same mistakes like what their partner had done.

Then, Peer editing technique is an authentic and interactive activities because the students did interaction with peer as authentic reader and editor. Thus, the students got reader's opinion and suggestion to improve their writing. Lyutaya (2011) says that students learn more deeply and understand when they are able to share ideas with others, considering alternative points of view, and broadening their own perspectives. According to Harmer (2007) students learn better if they enjoy the activities they are involved in. Moreover, the reader also became the authentic reader which had authority to judge the writing. Peer editor as reader interacted with writer about what should be improved or removed. It trained them to be more appreciative when giving suggestion. They also did interaction in the revising process. However, sometimes the writer was true and the reader as editor was wrong. It was the function of clarification. The writer clarified that what they have made was true by giving details explanation.

Further, Peer editing as teacher's technique covered teaching learning process from planning stage to revising stage. Thus, no missing stage is in the writing process. Nation 
(2009) states that the teachers have to provide some helps at the various stages of writing process rather than only to focus to the writing product. In peer editing technique, the students also actively involved in the teaching - learning process. It supports Harmer's (2007) opinion that the students will be motivated by the enjoyment of the learning process they are involved in. Peer editing technique has seven steps; (1) explaining characteristics of Recount text and showing the example, (2) demonstrating how to do peer editing, (3) making the first draft, (4) exchanging the first draft with their peer, (5) spotting the mistakes and fill in peer editing worksheet, (6) consulting with peer editor about the feedback given, (7) revising the first draft to be the final draft.

First, explaining characteristics of Recount Text and showing the example. It made students became more understand about the principles of Recount text. The researcher explained the characteristics of Recount text such as generic structure (orientation, events and reorientation) and language features (action verb, saying verb, adverb; time, place and manner, active past tense and passive past tense). Then, gave the example of Recount Text helped students to have a clear guidance about the text.

Second, demonstrating how to do peer editing. It made students understand more what should be edited and how to do it. Teacher demonstrated the way to edit the Recount Text by taking one students' first draft. She edited the first draft on the white board and opened for students' questions and suggestion. Then, the student that has the first draft sat in front of the class, answered the questions and commented on their friends' suggestions.

Third, making the first draft. The researcher guided students to write the first draft based on their pre writing text by using free writing technique in cycle I and outlining in cycle II. The students were creative to develop their ideas by using free writing technique. Then, by using outlining technique, the students were easier to deliver and develop their ideas more systematic and focus. Thus, pre writing technique helped students to be easier in developing their ideas in order to write the first draft based on generic structure (orientation, events and reorientation) and language features of Recount text. The students could write the first draft well because they had stimulated their ideas in the pre writing activity. Teacher really appreciated students' activity in each process.

Fourth, students exchanged the first draft with their peer. Both students exchanged their first draft each other. Then, they read their peer's writing carefully in order to find some mistakes. Further, they could give details feedback in order to make their peer has good writing product.

Fifth, spotting the mistakes in order to guide the peer to find their partner's mistakes in the text. Then, peer editor filled peer editing worksheet to guide students in editing process. Editing process was useful for students in order to know their mistakes because sometimes they could not find it but their peer editor could find.

Sixth, students consulting with peer editor about the feedback given for clarification because sometimes the writer was right and peer editor was false. According to Balushy (2013) students have to consult with peer editor for clarification. By clarification process, the students shared knowledge each other. Harmer (2007) states that students tend to participate more actively in pairs or group rather than in the whole class. Thus, they could be more understood about the principles of writing Recount text. When they were in doubt on their peer's explanation, they asked to the teacher for more explanation. As supports by Harmer (2006) the role of teacher in writing are as motivator, source of information, and feedback provider.

Seventh, students revising the first draft to be the final draft based on feedback from peer editor to have better writing. It was supported by the research finding from Arini (2012) which mentions that the use of peer editing and revising techniques can improve the students' writing ability, participation and response. In revising process, the students were conscious that their writing was not perfect. They needed an editor to explain some points that they did not understand. Thus, the students would have better writing as the final product by considering their peer editor feedback. Then, the researcher took revised draft as product grade. 
From the explanation above, we can see that the students' writing skill through peer editing technique are significantly improved. The use of peer editing technique solved the students' problem in writing class. Also, it can improve students' independence in writing. Finally, the use of peer editing was essentials to be considered in the teaching of writing.

This research implies that peer editing technique as a technique to solve some students' problems including organization of the text, content, grammar, mechanic, and vocabulary in writing Recount Text at session 2016 A English Department STKIP PGRI West Sumatera. It is appropriate with the research by Nahdi (2011), which consists of three cycles. Each cycle consists of three meetings to write paragraph draft, to exchange ideas with pair, to do peer editing, to revise the draft, and to discuss the students' difficulties. As a result, peer-editing technique can improve students' ability in writing an Expository paragraph and improve classroom situation in writing class. However, the difference is when Nahdi improved students' writing skill of Expository paragraph in three cycles, the researcher improved students' writing skill of Recount Text in two cycles.

Furthermore, Peer editing as teachers' technique covered teaching learning process from planning stage to revising stage. Thus, no missing stage was in the writing process. In peer editing technique, the students also actively involved in the teaching - learning process. It is appropriate with Baroroh (2011) which used mind mapping and peer-editing technique to improve the students' writing skill especially on the aspects of content, organization of ideas and language features. It is proved by the significant increase of the mean score of the posttest cycle 1 and post-test cycle 2 . Second, those techniques cover on the planning stage and revising stage in the process of writing. As the result, there is no missing stage from prewriting to post-writing. Third, students also actively involved in the teaching-learning process.

Then, Arini (2012) on the implementation of peer editing and revising techniques started by reviewing the argumentative essay, conducting pre-writing and drafting in groups. Then, the researcher gave modeling of peer- revising techniques. She asked the students to conduct peer editing and revising techniques based on the rubrics given and asked them to prepare for group presentation. Then, they publish their work on the wall board. The result of the study shows that the use of peer editing and revising techniques can improve the students' writing ability in writing argumentative essay. The students' participation and response was also achieved.

Moreover, Fajriah (2012) has done a research to Improve Students' Writing Skill in Descriptive Text through Brainstorming and Peer Editing Techniques. It was conducted in two cycles.The result of the study shows that brainstorming and peer editing techniques can improve students' writing skill in descriptive text. It proved through the increasing of writing score at the end of the second cycles. Students are also more activate and motivated in the teaching learning process. From the number of related studies above, it shows that peer editing technique contributes to good effect on the students' writing skill.

Marsh (2018) has found writers value reviews as important critical feedback. Research finding shows the social connection and support students provide to each other back grounded in these studies, which focus rather on writing quality improvement as the benchmark for peer feedback's effectiveness. All those researches are approprite with this research which is the students are given big opportunity to write the text and to edit their partner's writing. It is related to collaborative task because the success of their partner's writing related to some feedback that had been given by peer editor. They are also interdependent because dependent each other to finish the task of Recount Text. Moreover, students consult with their peer editor about the feedback given in editing process for clarification. Students had mutual interchange in clarification process because they exchanged some information with their peer. It is related to collaborative interaction. Their activity in editing and consulting the feedback make them skillful in bringing critical thinking that their writing is not perfect and they need an editor to make it better. Those are the advantages of peer editing technique. As the result, the students can develop their writing skill not only in Recount Text but also in other kinds of texts. In accordance with the findings of research, the suggestion can be given for the lecturer to helps students in improving their writing skill by using peer editing technique through implementation of those steps more 
detailed. For next researcher, it is suggested to improve students' writing skill through peer editing technique in others aspects or others kinds of writing skill.

\section{Conclusion}

Based on the findings and discussion of the students' writing skill by applying peer editing technique during two cycles of the classroom action research, it can be concluded that: First, the use of peer editing technique improve the students' writing skill better at session 2016 A English Department STKIP PGRI West Sumatera .The findings show that all of the indicators in this research including organization, content, grammar, mechanic, and vocabulary get progress in two cycles of the research.

Second, there are four important factors influencing students' writing skill on Reccount Text through peer editing technique. The first factor is topic, when students choose appropriate topic, they can develop their writing better. Second, connecting reading and writing, it helps students to find more information before writing, can edit well and do reflection independently. The third factor is authentic and interactive activities. Peer editing technique as an authentic and interactive activities, the students do interaction with peer as authentic reader and editor independently. The four factor is peer editing covering teaching learning process from planning to revising stage of writing process. In each step of writing process, the students should learn independently.

In accordance with the conclusion, the suggestions can be given as follows: First, for the teacher, peer editing technique is suggested to be used in the writing class to develop not only students' writing skill but also students' independence in writing. Thus, they learn writing deeply inside and outside the classroom. The teacher can implement those steps of peer editing technique more thoroughly. Second, for the next researcher, it is suggested to develop students' writing skill through peer editing technique in others kinds of writing text.

\section{Acknowledgment}

This research was supported or partially supported by DRPM DIKTI fund in 2017 . We thank our colleagues from STKIP PGRI Sumatera Barat which provided insight and expertise that greatly assisted the research, although they may not agree with all of the interpretations/conclusions of this paper.

\section{References}

Amato, R. and Patricia, A. (2003). Making It Happen.New York: Longman.

Arini, D. N. (2012). "Using Peer Editing and Revising in Process Approach to Improve the Students' Ability in Writing Argumentative Essay at Lambung Mangkurat University". Unpublished Thesis Abstract. Malang: UNM. Retrieved on January $24^{\text {th }} 2013$ fromhttp://karya-ilmiah.um.ac.id/index.php/disertasi/article/view/23751

Balusy, Z. (2013). Peer Editing. Language Centre,SultanUniversity. Retrivied on January $24^{\text {th }} 2013$ fromhttp://www.developinglecturers.com/articletchtraining/peeredpf

Baroroh,M. 2011. "The Use of Mind Mapping and Peer-Editing to Improve Students' Writing Skill (A Classroom Action Research Conducted at the Tenth Grade Students of SMA Negeri I Karanganyar in the Academic Year of 2010/2011)". Unpublished Thesis Abstract. Surakarta: UNS. Retrieved on January $24^{\text {th }} 2013$ fromhttp://digilib.fkip.uns.ac.id/contents/skripsi.php?id skr

Bolton,S.D. (2013). The Dialogue Journal: A Tool for Building Better Writers. English Teaching Forum. 2, pp. 4

Brown, H.D . 2001. Teaching by Principles: An Interactive Approach to Language Pedagogy. New York: Addison Wesley Longman, Inc.

Corbett, Pie and Julia Strong. (2011). Talk for Writing Across the Curriculum. New York: McGraw-Hill Companies.

Creswell, J. W. 2012. Educational Research: Planning, Conducting, and Evaluating Quantitative and Qualitative Research.Boston: Pearson.

Fajriah,A.2012. "Improving Students' Writing Skill in Descriptive Text through Brainstorming and Peer Editing Techniques at Third Grade Students' of Sentolo Kulon Progo" 
Unpublished Thesis Abstract. Yogyakarta: UNY. Retrieved on January $24{ }^{\text {th }} 2013$ from http://eprints.uny.ac.id/1196/

Gay, L.R. and Peter,A. 2000. Educational Research: Competencies for Analysis and Application. New Jersey: Prentice Hall, Inc.

Hadley, A. O. (2001). Teaching Language in Context. New York: Heinle\&Heinle.

Harmer, J. (2007). How to Teach English. Harlow: Pearson Longman.

Hedge, T. (2007). Teaching and Learning in the Language Classroom. New York: Oxford University Press.

Kemmis, S. and Robin, Mc. T. (ed.). (1998). The Action Research Planner (3 ${ }^{\text {rd }}$ ed). Victoria: Deakin University.

Knapp, Petter and Meggan Watkins. (2005). Genre Text Grammar: Technologies for Teaching and Assessing Writing. Sidney: University of New South Wales Press Ltd.

Lyutaya, T. (2011). Reading Logs:Integrating Extensive Reading with Writing Tasks. English Teaching Forum. 1, pp. 4.

Marsh, V.L. (2018). Portal and Gatekeeper: How Peer Feedback Functions in a High School Writing Class. Research in the Teaching of English .53, pp. 149-172.

Nahdi, M. 2011. 'Improving Students' Writing Ability by Using Peer Editing Technique (A Classroom Action Research at the Third Semester Students of English Study Program of STKIP Hamzanwadi Selong in Academic Year of 2010/2011)". Unpublished Thesis Abstract. Surakarta: UNS. Retrieved on January 24 th 2013 fromhttp://pasca.uns.ac.id/?p=1685

Nation, I.S.P. (2009).Teaching ESL/EFL Reading and Writing. New York:Routledge.

Oshima, A and Ann, H. (2007). Introduction to Academic Writing. New York: Pearson Longman.

Rathvon, N. (2008). Effectives School Interventions: Evidence- Based Strategies for Improving Student Outcomes. New York: Guilford Publications, Inc.

Wardiman, Antono. (2005). Make Your Self a Master of English. Jakarta: PT. Setia Purna Inves.

Weigle, Sarah Cushing. (2002). Assessing Writing. Cambridge: Cambridge University Press 